\title{
Urgences
}

\section{Qui ou quoi ?}

\section{Maurice Richard}

Numéro 13, mars 1986

\section{Éclats d'atelier}

URI : https://id.erudit.org/iderudit/025204ar

DOI : https://doi.org/10.7202/025204ar

Aller au sommaire du numéro

\section{Éditeur(s)}

Urgences

\section{ISSN}

0226-9554 (imprimé)

1927-3924 (numérique)

Découvrir la revue

\section{Citer ce document}

Richard, M. (1986). Qui ou quoi ? Urgences, (13), 23-23.

https://doi.org/10.7202/025204ar d'utilisation que vous pouvez consulter en ligne.

https://apropos.erudit.org/fr/usagers/politique-dutilisation/ 


\section{QUI OU QUOI? Maurice Richard}

Ma ville dort maintenant. "Miroir, miroir, qui a le plus gentil bébé? Avec le cristal de ses yeux, la brillance de son cheveu, votre fille incarne certainement le plus gentil petit minois que je connaisse." Une fois de plus un réconfort d'amnésique me gagne, m'amenant doucement à la chambre qui m'attend.

Radio bonjour, grincements de portes, bruits d'ustensiles, puis le silence s'installe fébrilement; mais, plus loin, les cordes à linge m'alertent, je suis en retard. Inquiet, je récupère la mémoire dans mon porte-document, toujours fourrée partout celle-là. Confirmé, "j'arrive, je nettoie ma première guitare: je veux vous la présenter, depuis le temps".

Emersion difficile, ensevelie dans le garde-manger, crottée jusqu'aux fibres.

Recoins du pied, bas du ventre, épaules arrondies, tout y passe, il faut que tu sois propre ma petite pincette. Identique enfin, je te revois, comme les souvenirs d'un rêve. "Certainement que le froid' s'habille, dépêchons-nous, la rue Dupont nous attend. Hem! le gang fait pas beaucoup de bruit. Ah! pas un autre ticket à prendre. Raisons à écouter, dire que je comprends malgré tout. Destination réalité, magie d'un rendez-vous ne revient jamais. Miroir! Miroir! 